ECOLOGICA, Vol. 28, No 101 (2021), 118-124

https://doi.org/10.18485/ecologica.2021.28.101.18

Originalni naučni rad

UDC: $502.11:[616.98: 578.834$

$33:[616.98: 578.834$

\title{
Posledice delovanja Covid-19 na ekonomski sektor i životnu sredinu
}

\section{Consequences of Covid-19 effect on the economic sector and the environment}

\author{
Olja Munitlak Ivanović ${ }^{1}$, Marko Vujić ${ }^{2}$ \\ 1 Univerzitet u Novom Sadu, Prirodno-matematički fakultet, Novi Sad, Srbija \\ 1 University of Novi Sad, Faculty of Sciences, Novi Sad, Serbia \\ 2Univerzitet u Beogradu, Fakultet političkih nauka, Beograd, Srbija \\ 2University of Belgrade, Faculty of Political sciences, Belgrade, Serbia
}

Rad primljen: 25.01.2021, Rad prihvaćen: 26.02.2021.

\begin{abstract}
Sažetak: Pandemija COVID-19 jenjava ali se nikako ne može raći da joj se baš vidi kraj. Bez masovne imunizacije, pod uslovom da se ne pojavi još neki od novih sojeva virusa, kraj ovoj planetarnoj pošasti se ni ne nazire. Od marta 2020. godine kada je proglašena pandemija COVID-19, broj zaraženih i preminulih se izražava stotinama hiljada i milionima ljudskih života, zavisno od države. Sasvim je sigurno da će nov način života i nove navike, koje smo stekli za prethodnih godinu dana, delimično postati deo naše nove svakodnevnice. Može se slobodno reći da je pandemija COVID-19 okarakterisala jednu eru ljudskog postojanja. Posledice izazvane pandemijom, su dotakle svaki deo života ljudi. Od krize javnog zdravlja, preko dubokih ekonomskih i društvenih posledica došlo je neminovno i do promene u životnoj sredini. Uticaj pandemije na globalnu ekonomiju a time i finansije je svakako negativan. Samo je pitanje brzine i spretnosti konkretne države i celokupnog njenog sistema da se prilagodi novonastaloj situaciji. Očigledno je da su potrebne promene u funkcionisanju zdravstvenog sistema, a zatim i ekonomskog sistema od čega zavisi funkcionisanje svih ostalih sistema koje čine jednu državu. Logično da je pandemija smanjila obim ekonomskih aktivnosti svake zemlje. Samo je pitanje razlike koliki je intenzitet pada tih aktivnosti meren različitim ekonomskim pokazateljima. Gašenje ili smanjenje obima rada pojedinih industrija je doveo do smanjenja aero i drugih vrsta zagađenja. Logičan sled smanjenja ekonomskih i industrijskih aktivnosti, rad i školovanje od kuće su doveli do smanjenja transporta a time i emisije te vrste štetnih gasova ali i smanjene upotrebe potrošene količine nafte. Smanjen je nivo emisija gasova sa efektom staklene bašte. Voda u morima, okeanima i rekama je zahvaljujući smanjenom obimu rada industrije, postala mnogo čistija a biodiverzitet voda se značajno oporavio. Ponovo su se pojavile životinjske i biljne vrste u svom prirodnom okruženju, kojih godinama nije bilo usled posledica zagađenja. Na kratko, u jednom periodu se čak smanjio i intenzitet zagrevanja naše planete. Novi problemi koji su se pojavili u oblasti životne sredine su oblici medicinskog i drugog otpada koji u sebi sadrže plastiku, otporni su na vodu i vreme razgradnje im je dugo, a često završavaju na neadekvatnim deponijama ili u vodama okeana i mora. lako je teoretski više puta dokazano, pokazalo se da dilema economija vs. ekologija nije slučajno postavljena. Uočeno je da postoji veza između klimatskih promena i pojave novih vrsta virusa. Samim tim planovi za nastavak života posle pandemije COVID-19 ali i planovi koji se tiču redukcije rizika od pojave novih virusa moraju se povezati sa ljudskim negativnim uticajem na životnu sredinu, shvaćeno u najširem smislu te reči. Nužno je smanjiti negativan uticaj čoveka i njegovih destruktivnih aktivnosti na životnu sredinu u cilju smanjenja rizika od pojave novih zaraznih bolesti. Jer i zarazne bolesti nastaju u prirodi. Na osnovu svega navedenog može se zaključiti da su obe hipoteze postavljene na početku rada dokazane.
\end{abstract}

Ključne reči: COVID-19, životna sredina, pandemija, ekonomske aktivnosti, gasovi staklene bašte.

${ }^{1}$ orcid.org/0000-0002-4323-3678, e-mail: olja.mi@dgt.uns.ac.rs

${ }^{2}$ orcid.org/0000-0002-7432-6367, e-mail: marko.vujic@fpn.bg.ac.rs 


\begin{abstract}
The COVID-19 pandemic is subsiding, but there is no way to say that its end is in sight. Without mass immunization, provided that some of the new strains of the virus do not appear, the end of this planetary plague is not even in sight. Since March 2020, when the COVID-19 pandemic was declared, the number of infected and dead has been expressed in the hundreds of thousands and millions. Depending on the country. It is quite certain that the "new" way of life and new habits, which we have acquired in the previous almost a year, will never be the same again. Or at least not in the foreseeable future. It is safe to say that the COVID-19 pandemic characterized an era of human existence. The consequences caused by the pandemic have affected every part of people's lives. From the crisis of public health, through the deep economic and social consequences, there has inevitably been a change in the environment. The impact of the pandemic on the global economy and thus on finances is certainly negative. It is only a question of the speed and dexterity of a particular state and its entire system to adapt to the new situation. It is obvious that changes are needed in the functioning of the health care system, and then the economic system, on which the functioning of all other systems that make up one state depends. It is logical that the pandemic reduced the scope of economic activities of each country. The only question is the difference in the intensity of the decline in these activities measured by different economic indicators. Shutting down or reducing the volume of work of certain industries has led to a reduction in aero and other types of pollution. The logical sequence of the reduction of economic and industrial activities and work and schooling from home have led to a reduction in transport and thus emissions of this type of harmful gases, but also a reduced use of the amount of oil consumed. The level of greenhouse gas emissions has been reduced. Water in the seas, oceans and rivers, thanks to the reduced volume of work of the industry, has become much cleaner and the biodiversity of water has significantly recovered. Animal and plant species have reappeared in their natural (aquatic) environment, which have not been present for years due to the consequences of pollution. In short, in one period, the intensity of warming of our planet even decreased. New problems that have appeared in the field of the environment are forms of medical and other waste that contain plastic, are resistant to water and have a long decomposition time, and often end up in inadequate landfills or in ocean and sea waters. Although it has been theoretically proven several times, it has been shown that the economics dilemma versus ecology is not accidentally posed. It has been noticed that there is a connection between climate change and the appearance of new types of viruses. Therefore, plans to continue living after the COVID-19 pandemic, but also plans to reduce the risk of new viruses, must be related to human negative impact on the environment, understood in the broadest sense of the word. It is necessary to reduce the negative impact of man and his destructive activities on the environment in order to reduce the risk of new infectious diseases. Because infectious diseases also occur in nature.
\end{abstract}

Keywords: COVID-19, environment, pandemic, economic activities, greenhouse gases.

\section{UVOD / INTRODUCTION}

Pandemija COVID-19 u Srbiji i na globalnom nivou blago jenjava, praćena strahom kako će novi oblici sojeva COVID-19 uticati na dalji život. Više je nego jasno da su ekonomski, društveni i socijalni život svakog društva tokom 2020. godine pretrpeli velike promene. Postavlja se i pitanje da li će život nakon pandemije koja je na svetskom nivou proglašena 11. marta 2020. godine, ikada više biti isti. Posledice su dugoročne $i$ još uvek njihovo dejstvo ne može ni da se pretpostavi. Svi stubovi koji čine koncept održivog razvoja su pretrpeli neku vrstu promene usled delovanja pandemije, a time je pitanje održivog razvoja i životne sredine ponovo dobilo na značaju. Dejstvo COVID-19 se ne može izolovano posmatrati kao zdravstveni, ekonomski, finansijski ili društveni problem [1]. Tako se posledicama mora i prići - interdisciplinarno. Paradoks je što je pandemija imala i neke dobre posledice, pre svega na zagađenje, energetski sektor, biodiverzitet odnosno na pitanja koja se odnose na životnu sredinu. Pozitivni efekti su se uočili odmah nakon proglašenja pandemije i mada su bili kratkoročni, otvorili su pitanje da se sa naučnog stanovišta proveri da li se ovaj pozitivni efekat može produžiti.

\section{MATERIJALI I METODE / MATERIALS AND METHODS}

Ovaj rad je zasnovan na desk research metodi, metodi komparacije, proučavanju i analiziranju knjiga, naučnih radova, sajtova i svih naučnih objavljenih tekstova koji se odnose na fenomen "Crnog labuda", pandemiju COVID-19 odnosno uticaj pandemije na ekonomske pokazatelje na globalnom i nacionalnom nivou kao i uticaj pandemije na energetski sektor. Zatim, korišćene su metode indukcije i dedukcije u donošenju zaključaka. Kretalo se od pojedinačnog ka opštom, i sasvim suprotno od opšteg zaključka ka pojedinačnom stavu.

Hipoteza od koje se krenulo je da je pandemija COVID-19 imala negativan uticaj kako na ekonomiju tako i na energetsku privredu. Druga hipoteza se odnosi na uticaj COVID-19 na životnu sredinu, gde je pretpostavka da je uticaj pandemije bio više pozitivan nego negativan, ali da je imao značajan uticaj na životnu sredinu. 
$U$ radu su priložena i dva grafikona koji ilustruju i dokazuju ispravnost postavljene prve hipoteze. Prvi grafikon prikazuje emisiju gasova u vreme pandemije i bez nje odnosno daje predikcije emisije gasa $\mathrm{CO}_{2}$ za period do 2050. godine. Drugi grafikon, pak prikazuje kretanje trgovine EU ETS od 2008. godine, sa predviđanjem njihovog oporavka odnosno rasta do 2023. godine.

\section{REZULTATI / RESULTS}

\section{Covid-19 kao "crni labud" / Covid-19 as "black swan"}

Neki ekonomski teoretičari su pošast pandemije COVID-19 determinisali kao fenomen poznat kao "Crni labud" ("Black Swan"). Realan događaj za koji se vezuje ovaj termin je otkriće pojave crnog labuda kao nove životinjske vrste u Australiji 1967. godine (Hanić, 2020), jer se do tada smatralo da labudovi mogu biti samo bele boje. Ekonomski teoretičar Nassim Nicholas Taleb je 2007. godine uveo ovaj pojam u ekonomsku teoriju (Taleb, 2016). Da bi se događaj opisao kao "Crni labud" treba da ga karakterišu sledeće tri osobine:

1. Retkost u pojavljivanju,

2. Izuzetno velik uticaj i značaj na ekonomiju,

3. Ipak postoji mogućnost retrospektivne predvidljivosti.

Pandemija COVID-19 ima sve ove tri navedene karakteristike pa ga određen broj ekonomista smatra upravo "Crnim labudom" (Kanniahet al., 2020; Eroglu, 2020; Huremović, 2019). Znači "Crni labud" je fenomen koga karakterišu retkost, veliki značaj i retrospektivna predvidljivost (Taleb, 2016). Bitno je pomenuti da se "Crni labud" takođe odnosi i na neki događaj koji će se sa velikom verovatnoćom desiti, i očekuje se, ali se to ipak u praksi ne desi. Znači, radi se o događaju gde se na globalnom nivou od menadžera očekuje da nešto promene u ekonomskoj praksi ali se očekuje i od društva da promeni svoje norme i ponašanja.

Međutim, suština je da ljudi ovakvu vrstu događaja ipak sačekaju a da nisu spremni jer se bave tekućim ekonomskim, ekološkim, društvenim i političkim problemima, u nadi da se loš događaj ipak neće desiti. Iz tog razloga su posledice ovakvih dešavanja duboke i sa velikim negativnim posledicama.

Neki teoretičari izjednačavaju svaku krizu i "Crnog labuda" bez obzira na veličinu i znagu krize, i takav stav nije istravan (Hajikazemi et al., 2016). Prirodne nepogode koje se javljaju prema poznatom ciklusu ne spadaju u ovu vrstu fenomena. Ali ako se prirodna nepogoda ili neki drugi događaj, kao velika ekonomski kriza ili pandemija, dese neočekivano sa izuzetno velikim posledicama onda je reč o "Crnom labudu". Primer takvog fenomena u prošlosti jeste uragan Katrina koji je pogodio Sjedinjene države 2005. godine, posebno južnu obalu i grad Nju Orleans.

Raniji događaji koji su opisani kao "Crni labud":

- Naftna kriza: 1973. godine,

- Kriza u Iranu sa taocima: 1979. godine,

- "Crni ponedeljak": 1987. godine,

- Zalivski rat: 1991. godine,

- Ekonomska kriza u Azijskim zemljama: 1997. godine,

- Rušenje kula u Njujorku: 11. septembra 2001. godine,

- Pandemija SARS: 2003. godine,

- Svetska ekonomska kriza: 2008. godine,

- Rat u Libiji: 2011. godine,

- BREXIT: 2016. godine.

Ovi događaji nose epitet "Crnog labuda" iz ekonomskih razloga, jer su imali za posledicu značajan pad S\&P 500 indeksa a trajanje pada indeksa nije zanemarljivo (advisor.visualcapitalist, etc.).

\section{Uticaj pandemije covid-19 na globalnu ekonomiju / \\ the impact of the covid-19 pandemic on the global economy}

Uticaj pandemije COVID-19 na ekonomiju nikako ne može biti pozitivan, ali ni posledice ove vrste ekonomske krize ne mogu da se reše kao što su rešeni izazovi krize iz 2008. godine. Ova vrsta ekonomske krize nije pogodila samo zemlje sa niskim i srednjim bruto domaćim proizvodom (Janković, Ivannikov, 2017). Pandemija je ipak na neki način ujedinila svet na globalnom nivou, visina kamatnih stopa je na izuzetno niskom nivou a ponuda i tražnja imaju tendenciju pada (Munitlak-Ivanović, 2016).

Razlozi zbog kojih je pandemija toliko jako uticala na ekonomiju su višestruki. Jedna od posledica socijalne distance je ekonomski problem u obliku nestanka finansijskih tržišta što je uticalo na nestanak i gašenje mnogih preduzeća, što je imalo za posledicu rast nezaposlenosti i pad ekonomske aktivnosti. Kako će se situacija dalje odražavati na ekonomske i društvene sisteme zavisi od brzine zaustavljanja virusa, uticaja masovne imunizacije vakcinacijom na globalnom nivou, aktivnosti država u oblasti monetarne i fiskalne politike i moguće urušavanje bankarskog sistema (Munitlak-Ivanović i dr., 2015). Ekonomski kanali kojima se širi domino efekat COVID-19 na ekonomiju su: smanjenje na strani potrošnje proizvoda i usluga, šokovi nastali na finansijskim tržištima koje imaju posledice na realnu ekonomiju i poremećaji koji su nastali u lancu 
snabdevanja potrošača (Carlsson-Szlezak et al., 2020). Sve navedeno utiče na smanjenje obima stranih direktih investicija u odnosu na prethodne godine. Naša zemlja bi u tom smislu trebalo da se opredeli za aktivnu fiskalnu politiku i na taj način da pokuša da privuče inostrane investicije (Loayza et al., 2020).

Da bi se utvrdilo kako odgovoriti na novonastale nepredviđene ekonomske probleme, mnoge vlade, su intervenisale novom pravnom regulativom i različitim dokumentima koji su imali za cilj da ublaže ili eliminišu ekonomske probleme. Broj ovih radnih dokumenata je imao drastičan rast tokom 2020. godine (Brodeur et al., 2020). U posmatranom periodu došlo je do naglog rasta ovih dokumenata koji su realizovali predložene mere u veoma ograničenom vremenskom periodu. U ovom slučaju pre svega se misli na monetarne, fiskalne i druge finansijske mere i politike, koje su u datim uslovima dale najbolje rezultate koje su mogle.

\section{Uticaj pandemije na životnu sredinu /}

The impact of the pandemic on the environment

Kao posledica pada ekonomske aktivnosti, fizičkog distanciranja i rada od kuće, pojavili su se neki fenomeni koji nisu bili očekivani. Veliki deo industrijskih postrojenja je smanjio proizvodnju i kao posledica toga smanjen je pritisak na transport što je dovelo do naglog pada GHG (Gourinchas, 2020).
Međutim, sve ove promene imaju i čitav niz neočekivanih konsekvenci. Kako se ugasio veliki deo industrije, tako su relaksirani transportni sistemi i tako se ugasio veliki broj preduzeća, što je izazvalo na nagli pad emisije gasova sa efektom staklene bašte (Saadat el al., 2020). Socijalno distanciranje i smanjenje ekonomskih aktivnosti, smanjen rad elektrana i industrijskog sektora koji je uticao na pad ekonomskih aktivnosti je doveo do toga da su određeni teoretičari zauzeli stav de će se emisije GHG smanjiti toliko da će pasti na nivo koji je najniži od Drugog svetskog rata. Došlo je i do intenzivnog smanjenja emisije količine azotdioksida $\mathrm{PM}_{2.5}$ čestica u vazduhu.

Jedna od neočekivanih posledica smanjenja emisija GHG je bila aprila 2020. godine. U pitanju je kratkotrajno zahlađenje Zemlje u odnosu na isti period prethodne godine. Ipak se ovo ne može uzeti kao posledica sa dugoročnim efektima. Stoga autori ovog rada predlažu favorizovanja oblika ekonomije koja bi imala održiv karakter, kao što su oblici proizvodnje koje karakteriše smanjenje korišćenja fosilnih goriva. $U$ principu, ekonomiju bi trebalo zasnivati na proizvodnji sa niskim emisijama ugljenika tzv. low-carbon economy (Mitić i dr., 2017).

Kako i koliko dugo će emisija $\mathrm{CO}_{2}$ imati makar i kratkoročnu silaznu putanju, zavisi od trajanja pandemije ali i od cena nafte i količine upotrebe uglja $u$ procesu proizvodnje.

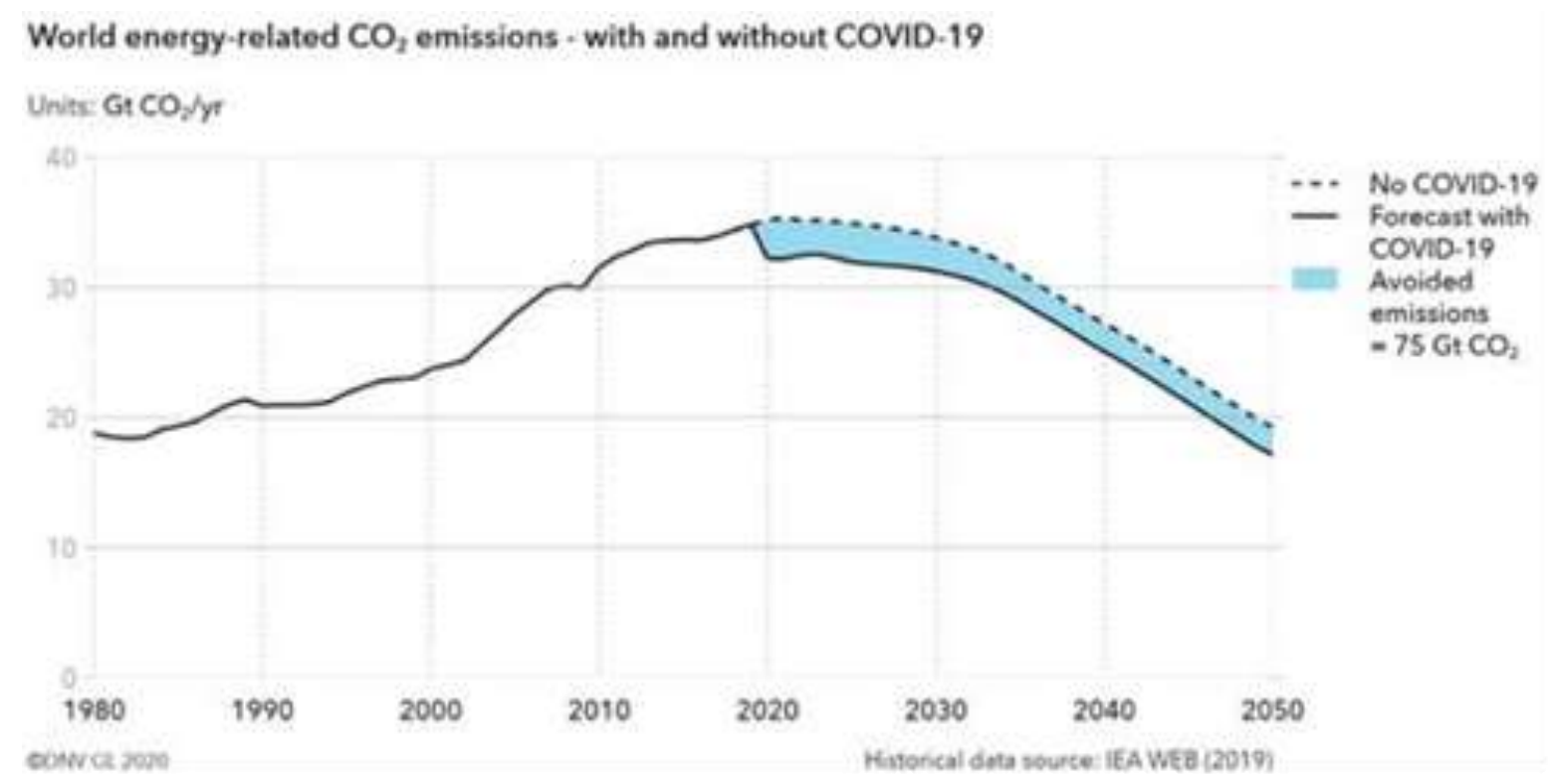

Grafikon 1 - Emisije $\mathrm{CO}_{2}$ iz energije - sa postojanjem i bez COVID-19

Graph $1-\mathrm{CO}_{2}$ emissions from energy - with and without COVID-19

Izvor / Source: https://www.dnvgl.com/energy-transition/impact-of-covid19-on-the-energy-transition.html 
$\mathrm{Na}$ grafikonu 1 se vidi očekivanje pada emisija štetnih gasova do 2050. Nije verovatno za očekivati da će pandemija biti jedini uzrok pada ovih emisija dugoročno posmatrano. Teoretičari Alvik i Irvin, ipak ne očekuju da će predviđena energetska tranzicija biti dovoljno brza kako je propisano Pariskim ugovorom odnosno nameri da se globalno zagrevanje održi ispod $2^{\circ} \mathrm{C}$ u odnosu na predindustrijski nivo (Alvik, Irvine, 2020).

I pored redukcije zagađenja, kada je reč o dve najpogođenije zemlje na početku pandemije $u$
Evropi (Španija i Italija) u martu 2020. godine došlo je do pada u sistemu trgovine emisijama gasova sa efektom staklene bašte (engl. European Union Emission Trading System, EU - ETS) koji funkcioniše po principu da se ekonomski odredi cena štetnih gasova koje jedno preduzeće emituje. Prva očekivanja su išla u smeru pada emisija EU ETS-a u vrednosti od 388,8 miliona tona za 2020 . godinu u poređenju sa identičnim periodom od pre godinu dana. Taj odnos je prikazan na grafikonu 2.

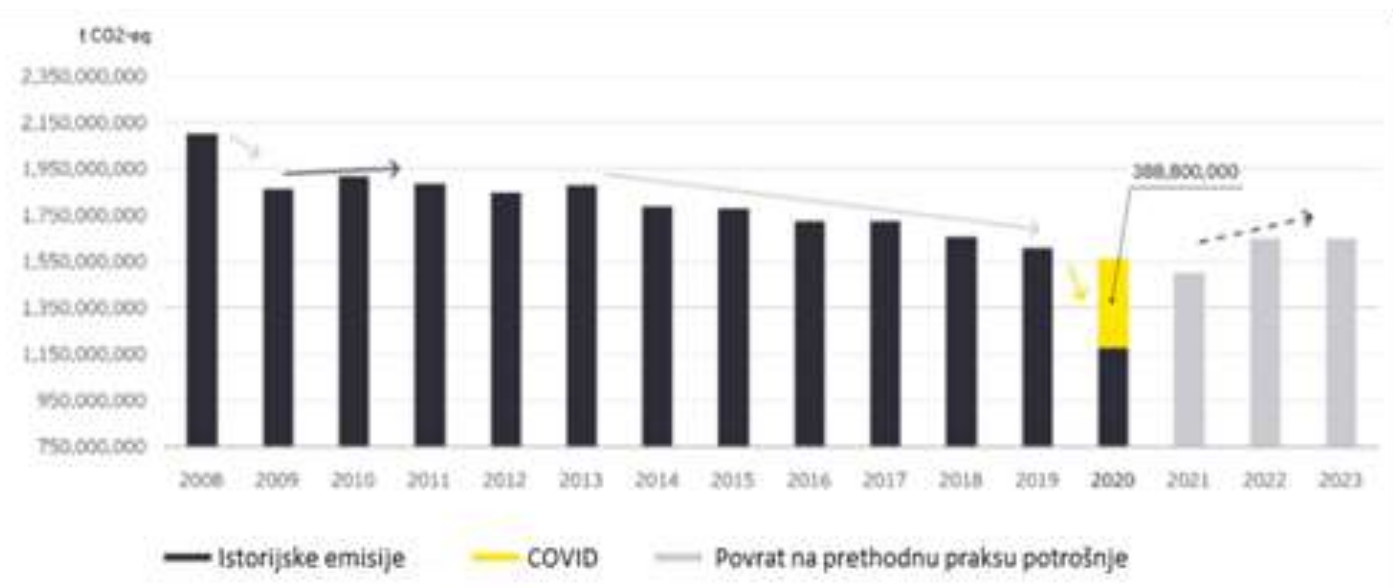

Grafikon 2 - Podaci trgovanju EU ETS u periodu 2008-2023. godine sa procenama

Graph 2 - EU ETS trading data for the period 2008-2023. years with estimates

Izvor Source: https://www.ey.com/en_gl/eu-institutions/how-europe-s-post-COVID\%19-economy-andenvironment-can-both-prosper

Na prethodnoj slici može da se vidi da je za vreme poslednje Svetske ekonomske krize došlo do situacije kada se pojavio višak dozvola za trgovanje emisijama. Da se to ne bi ponovilo, 2019. godine stvorena je rezerva za stabilnost tržišta za momentalno (automatsko) usklađivanje ponude dozvola u odnosu na stvarnu tražnju. Kao posledica toga došlo je do oporavka kretanja cene za emisione jedinice (engl. European Union Allowance ili skraćeno EUA) već sredinom godine. $\mathrm{Na}$ ovaj način je dokazano da je sistem EU ETS izdržao "test" i pokazao je svojevrsnu otpornost na delovanje pandemije.

Ova činjenica je od izuzetnog značaja jer je prihod od trgovanja emisijama EU ETS u 2019. godini u zemljama koje su uključene u ovaj sistem trgovanja doneo iznos od čak 45 milijardi \$.

Pored navedenih "pozitivnih", ako išta može biti okarakterisano kao pozitivno u uslovima pandemije, uočeni su i negativni uticaji na životnu sredinu. Ono što ima loš uticaj na životnu sredinu jesu nove odnosno dodatne količine raznog otpada. Maske koje se upotrebljavaju svakodnevno usled preventive i zaštite od zaražavanja, se sastoje od sirovina sačinjenih od plastike a koji su istovremeno rezistentni na tečnost. Problem vezan za ovu vrstu novog a masovnog otpada je što se teško razlažu nakon upotrebe a njihov ciklus se završava na nezaštićenim i za to nepredviđenim deponijama ali i vodenim tokovima i površinama okeana. Jedna od potencijalnih vrsti maski koje se koriste i treba da se menjaju barem jednom dnevno, su hiruške maske. Plastične boce od sredstava za dezinfekciju ruku i prostora, rukavice i razni medicinski otpadi takođe završavaju u životnoj sredini (Saadat el al., 2020).

Neke od profesija su više ugrožene i izložene riziku od negativnih efekata. Tu se misli na one koji su $u$ intenzivnijem kontaktu sa medicinskim otpadom, svi koji se bave sakupljanjem smeća i čišćenjem, zatim ljudi koji radno vreme provode na radnim mestima sa velikom frekvencijom stanovništva (radnici u prodavnicama i na pijacama, šalterski radnici i slično).

Kako je jedna od osnovnih preporuka rad od kuće, dolazi do nekih novih pojava, pored fizičkog i socijalnog distanciranja. Preporučeno je i obrazovanje (osnovno i delimično visoko obrazovanje) po principu on-line nastave, što znači opet od kuće. 
Sve to je uticalo da dođe do migracije populacije. Sve više su se naseljavala do tada pusta i prazna ruralna područja a gradska su ostajala sve praznija. Time se dovelo u opasnost lokalno stanovništvo ruralnog područja i njihove navike, a time je rasla i raste mogućnost širenja infekcije na tom području. Kao posledica rada od kuće, se stvara novi i pojačani pritisak na prirodu i infrastrukturu ruralnih područja, jer migracija se kreće i ka prigradskim područjima.

Kako ekonomija ima svoju logiku ovi procesi su doveli do situacije koja dugo nije bila prisutna na tržištu nekretnina. Naime, cene nekretnina u ruralnim područjima su dobile trend rasta. To je zaista velika novina, jer tržište na tim područjima je dugo vremena "mrtvo" obzirom da su migracije populacije imale obrnut smer, od ruralnih ka urbanim područjima. Ovo je naravno posledica "zaključavanja" ljudi u stanove ograničenog prostora.

\section{DISKUSIJA / DISCUSSION}

Tako je globalna tragedija zvana pandemija COVID-19 imala dvostruki uticaj. Ova pojava je generalno negativna po ljudsku populaciju zbog masovnih oboljenja, visoke smrtnosti populacije na globalnom nivou, smanjenja svih ljudskih aktivnosti (društvenih, kulturnih, sportskih i drugih). Zatim, došlo je do generalnog smanjenja individualnih prihoda i intenziviranja prisustva i veličine jaza siromaštva. Međutim, rezultati u obliku čistije životne sredine nisu zanemarljivi. Konačno je dokazana teorija da je zdrava životna sredina uslov za zdravu populaciju i opstanak ljudi. Bilo bi dobro da se ova činjenica dugo pamti, jer su ljudi skloni brzom zaboravljanju i potiskivanju sećanja na činjenice koje im se trenutno (po pravilu kratkoročno) čine nevažnim (Janković i dr., 2020).

Oba grafikona su pokazala da novi oblici proizvodnje imaju pozitivne uticaje na životnu sredinu u obliku manje emisije GHG ili kretanje cena prilikom trgovanja EU ETS. Novi načini proizvodnje bi trebalo da se zasnivaju na cirkularnoj a ne linearnoj ekonomiji, odnosno ekonomiji sa što manje otpada (Radović., 2020), (Arsić i dr., 2020). Suština cele ideje je da proizvodnja ima održiv karakter (Radoičić, Arsić, 2020). Drugo važno pitanje koje se nameće iz ovog rada je potreba za novim oblicima proizvodnje koji se znatno manje oslanjaju na upotrebu fosilnih goriva (Cvetanović i dr., 2020). Generalno posmatrano, celu ekonomiju treba bazirati na oblicima proizvodnje koje imaju nizak nivo emisije ugljenika tzv. low-carbon economy (Vuković i dr., 2020).

\section{ZAKLJUČAK / CONCLUSION}

Pojava pandemije COVID-19 nas je dočekala nespremne. Kako ovaj fenomen ima sledeće tri karakteristike: 1. Retkost u pojavljivanju, 2. Izuzetno velik uticaj i značaj na ekonomiju i 3. Postoji mogućnost retrospektivne predvidljivosti, za njega se može reći da je to fenomen koji se karakteriše kao "Crni labud".

Ne postoji deo sveta, region, država ili bilo koji geografski ili geopolitički pojam koji je ostao nepogođen delovanjem pandemije. Pandemija još traje. Sva očekivanja i nadanja ka povratku starom društvenom sistemu su usmerena na masovnu imunizaciju, uz pretpostavku da će postojeće vakcine biti otporne i na nove sojeve virusa koji se pojavljuju.

Rad od kuće, obrazovanje od kuće, kupovina iz kuće, virtuelno prisustvovanje kulturnim zbivanjima i virtuelni obilasci turističkih atrakcija samo su jedan pokušaj da socijalna distanca zameni fizički nedostatak ljudi, obavljanje posla sa radnog mesta, odlazak u obrazovne institucije, fizička komunikacija i slično. Ali ljudi su društvena bića i sa nestrpljenjem očekuju povratak starim radnim, sportskim, kulturnim i svim drugim društvenim i poslovnim dešavanjima.

Kao nikad do sada postalo je jasno da je koncept održivog razvoja i zaštite životne sredine jedini dugoročno mogući način života ukoliko ljudska vrsta želi da opstane na ovoj planeti. Dokazalo se da u bitci između prirode i čoveka uvek pobedi priroda.

Smanjenje svih poslovnih aktivnosti koji je doveo do smanjenja skoro svih oblika zagađenja, je imao za posledicu kratkotrajni oporavak životne sredine. Koliko će biti dugotrajan taj oporavak zavisi od nas samih. Dilema je da li ćemo (a možemo) ekonomske i industrijske aktivnosti urediti i postaviti tako da nam je jedan od primarnih ciljeva očuvanje životne sredine a ne samo rast produktivnosti, masovna proizvodnja i potrošnja i naravno porast profita. Jer, priroda je vrlo upečatljivo pokazala da ni oni koji su ostvarivali najveće profite nisu imuni na pandemiju, bez obzira da li se ova pojava posmatra na individualnom ili globalnom nivou.

\section{LITERATURA / REFERENCES}

[1] Advisor.visualcapitalist: https://advisor.visualcapitalist.com/blackswan-events/; https://www.forbes.com/sites/greatspeculation s/2014/01/31/asian-currency-crisis-was-nostock-market-killer/\#12db19183474; https://www.nasdaq.com/articles/same-crashseparated-13-years-2010-05-10 
[2] Alvik, S., Irvine, M. (2020). The Impact of COVID-19 on Energy transition, pp. 5-15.

[3] Arsić, Lj., Premović, J., Milićević, Z., Đokić, N., Stošić, N. (2020). Afirmacija modela cirkularne ekonomije u malim i srednjim preduzećima, Ecologica, 27(100), 647-644.

[4] Brodeur, A., Gray, D., Islam, A., Bhuiyan, S.J. (2020). A literature Review of the Economics of COVID-19. Institute of Labor Economics, pp. 13411.

[5] Carlsson-Szlezak, P., Reeves, M., Swartz, P. (2020). Understanding the Economic Shock of Coronavirus. Harvard Business Review, 1-19.

[6] Cvetanović, S., Turanjanin, D., Mandić, S. (2020). Theoretical explanations for the interdependence of economic growth and environmental quality, Ecologica, 27(98), 345-350.

[7] Eroglu, H. (2020). Effects of Covid-19 outbreak on environment and renewable energy sector. Environment, Development and Sustainability, pp. 1-9.

[8] Gourinchas, P.O. (2020). Flattening the pandemic and recession curves. In: Mitigating the COVID Economic Crisis: Act Fast and Do Whatever. London, pp. 31-40.

[9] Hajikazemi, S., Ekambaram, A., Andersen, B., Zidane, Y, J-T. (2016). The Black Swan Knowing the unknown in projects. 29th World Congress International Project Management Association, 22, pp. 184-192.

DOI: 10.1016/j.sbspro.2016.06.178

[10] Hanić, A. (2020). Crni labud u svetskoj ekonomiji, Black Swan in the World Economy 2020, Beograd, pp. 9-28.

[11] Hanić, A., Mitić, P. (2020). Uticaj COVID-19 na životnu sredinu i energetski sektor, Black Swan in the World Economy 2020, Beograd, pp. 141-157.

[12] Huremović, D. (2019). Brief History of Pandemics (Pandemics Throughout History). U: Huremović (eds), Psychiatry of Pandemics: $A$ Mental Health Response to Infection Outbreak. Springer, $64 \mathrm{p}$.

doi: 10.1007/978-3-030-15346-5_2.
[13] Janković M., Ivanikov N. (2017). Održivi razvoj i ekonomski rast. Ecologica, 24(87), 507-517.

[14] Janković, M., Jovanović, L., Krasulja, N. (2020). Značaj informacionih tehnologija u formiranju modela održivog razvoja, Ecologica, 27(98), 240-247.

[15] Kanniah, K.D., Fatihah, N.A., Zaman, K., Kaskaoutis, D.G., Latif, M.T. (2020). COVID19 's impact on the atmospheric environment in the Southeast Asia region. Science of The Total Environment, 736, 1-11. doi: 10.1016/j.scitotenv.2020.139658.

[16] Loayza, N., Pennings, S., (2020). Macroeconomic Policy in the Time of COVID-19: A Primer for Developing Countries. World bank Group, pp. 1-9.

[17] Mitić, P., Munitlak Ivanović, O., Zdravković, A. (2017). A cointegration analysis of real GDP and $\mathrm{CO}_{2}$ emissions in transitional countries. Sustainability, 9(4), 568. doi.org/10.3390/su9040568

[18] Munitlak Ivanović, O. (2016). Praćenje prihoda od ekoloških poreza u EU-28 metodom tempa porasta. Ecologica, 23(82), 167-170.

[19] Munitlak Ivanović, O., Raspopović, N., Mitić, P., Jovanović L. (2015). Kvantifikacija društva u smislu održive privrede. Ecologica, 74, 165168.

[20] Radoičić, J., Arsić Lj. (2020). Cirkularna ekonomija - putokaz ka zelenim radnim mestima, Ecologica, 27(98), 332-339.

[21] Radović, N. (2020). Primena Blockchain-a u sektoru obnovljivih izvora energije, Ecologica, 27(100), 572-578.

[22] Saadat, S., Rawtani, D., Hussain, C. M. (2020). Environmental perspective of COVID-19. Science of The Total Environment, 728, 138870. doi.org/10.1016/j.scitotenv.2020.138870

[23] Taleb, N.N. (2016). Crni labud: Uticaj krajnje neverovatnih zbivanja. Heliks, Beograd, 472 p.

[24] Vuković, A., Riznić, D., Vuković, M. (2020). Cirkularna ekonomija u funkciji regeneracije prirodnih ekosistema, Ecologica, 27(98), 209216. 